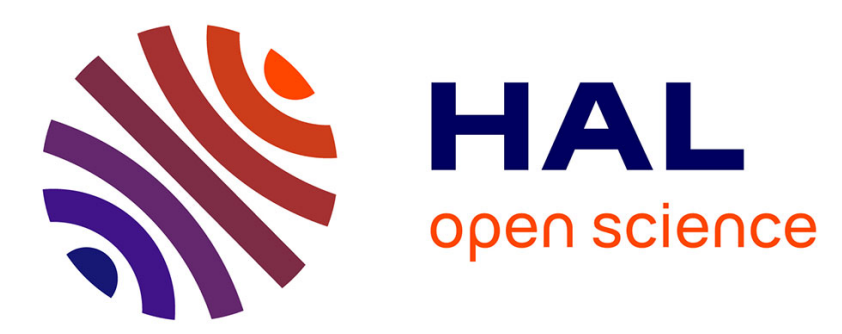

\title{
Electron Properties of Carbamazepine Drug in Form III
}

Nouha El Hassan, Aziza Ikni, Jean-Michel Gillet, Anne Spasojevic-de Bire, Nour Eddine Ghermani

\section{To cite this version:}

Nouha El Hassan, Aziza Ikni, Jean-Michel Gillet, Anne Spasojevic-de Bire, Nour Eddine Ghermani. Electron Properties of Carbamazepine Drug in Form III. Crystal Growth \& Design, 2013, 13 (7), pp.2887-2896. 10.1021/cg4002994 . hal-02270731

\section{HAL Id: hal-02270731 \\ https://hal.science/hal-02270731}

Submitted on 24 Sep 2020

HAL is a multi-disciplinary open access archive for the deposit and dissemination of scientific research documents, whether they are published or not. The documents may come from teaching and research institutions in France or abroad, or from public or private research centers.
L'archive ouverte pluridisciplinaire HAL, est destinée au dépôt et à la diffusion de documents scientifiques de niveau recherche, publiés ou non, émanant des établissements d'enseignement et de recherche français ou étrangers, des laboratoires publics ou privés. 


\section{Electron Properties of Carbamazepine Drug in Form}

\section{III}

Nouha El Hassan, ${ }^{\dagger}$ Aziza Ikni,,${ }^{\dagger}$ Jean-Michel Gillet,${ }^{\dagger}$ Anne Spasojevic-de Biré, ${ }^{\dagger}$ and Nour Eddine Ghermani $^{*, L, t}$

$\dagger$ Laboratoire Structures, Propriétés et Modélisation des Solides (SPMS) UMR CNRS 8580, Ecole Centrale Paris, 1, Grande Voie des Vignes, 92295 Châtenay-Malabry, France.

${ }^{\perp}$ Institut Galien Paris Sud, UMR CNRS 8612, Université Paris Sud, Faculté de Pharmacie, 5, rue Jean-Baptiste Clément, 92296 Châtenay-Malabry, France.

RECEIVED DATE (to be automatically inserted after your manuscript is accepted if required according to the journal that you are submitting your paper to)

* Corresponding author. Fax: +33 (0)1 468358 82, Tel: +33 (0)1 46835648

E-mail address: noureddine.ghermani@u-psud.fr 
ABSTRACT: The experimental electron and electrostatic properties of carbamazepine drug molecule (form III) were determined from accurate high resolution X-ray diffraction data collected at $100 \mathrm{~K}$. The results are compared to quantum mechanics calculations for gas-phase molecule and multimers. The experimental electron density was refined using the HansenCoppens multipole formalism and the deformation electron density maps are compared to the theoretical ones. Both experimental and theoretical deformation electron density maps presented here are based on Clementi's promolecule densities used as a reference. The topological analysis of the carbamazepine electron density using Bader's theory has been carried out and the integrated atomic charges are presented and compared to those obtained for molecules with equivalent chemical fragments. The charge values compare qualitatively well with those obtained by theoretical calculations. The electrostatic potential features and the interaction electrostatic energies are also discussed. 


\section{INTRODUCTION}

Carbamazepine (hereafter CBZ, Figure 1), 5H-dibenz[b, f]azepine-5-carboxamide, is a first generation anticonvulsant drug used in the treatment of epilepsy and trigeminal neuralgia. CBZ pharmacologically interacts with nicotinic receptors. It was shown that aromatic-aromatic interactions ( $\pi-\pi$ stacking) occur between CBZ phenyl rings and the normal or the mutant neuronal $\alpha 4 / \beta 2$ nicotinic acetylcholine receptor Phe248 phenylalanine residues. ${ }^{1}$ Furthermore, it was found that the carbamyl group of CBZ forms hydrogen bonds with serine and probably threonine residues present in the ion channel of the nicotinic receptor. ${ }^{1}$ Human cytochrome P450 CYP3A4, one of the major metabolizing enzymes, catalyzes the 10,11-epoxidation of carbamazepine. Different molecular docking simulations have been performed in order to establish the metabolism mechanism. ${ }^{2,3}$ Solid state structures of CBZ have been extensively studied. In the crystalline state, CBZ exhibits four polymorphs (I to IV). The most thermodynamically stable polymorph is the $P$-monoclinic form III of CBZ which has been structurally studied in the 80 's. ${ }^{4,5,6}$ Structures of trigonal form $\mathrm{II}^{7}$ and $C$-monoclinic form $\mathrm{IV}^{8}$ of CBZ have also been determined by X-ray diffraction experiments. More recently the structure of the high-temperature triclinic form I of CBZ was reported and compared to those of the other forms. ${ }^{9}$ The crystal structure prediction of the four polymorphs of CBZ was also determined from lattice energy minimization. ${ }^{10}, 11$ In this latter study, the contribution of the amide pyramidalization of CBZ on the lattice energy calculation outcomes was emphasized. Therefore, the observed relative thermodynamic stability of the different forms of the title compound was confirmed. ${ }^{10,11}$ 
During the conventional crystallization process, the CBZ metastable form II can coexist with form III and the influence of stirring the solutions on polymorphic transformations of CBZ from, for example, anhydrous ethanol solvent has recently been observed. ${ }^{12}$ Moreover, the disorder of the solvent molecules included in the crystal lattice empty channels of form II of CBZ obtained by slow evaporation of different solvents (toluene, n-tridecane, THF) has been carefully analyzed using conventional and sophisticated methods..$^{13,14,15}$ On the other hand, the study of pseudopolymorphs and essentially solvates of CBZ has also been carried out from other routes of crystallization i.e. nonionic microemulsions. ${ }^{16}$ Extensive combined theoretical and experimental works have been done on CBZ pseudopolymorphs using various methods. ${ }^{17,} 18$ Alternatively, the solid state NMR was conducted to characterize the structures of the polymorphs and pseudopolymorphs of $\mathrm{CBZ}$ and confirm the results of X-ray diffraction experiments. ${ }^{19}$ Structures of cocrystals containing the CBZ molecule have also been explored. CBZ cocrystals exhibit polymorphism as for CBZ-nicotinamide and CBZ-saccharin compounds. ${ }^{20,} 21$ In the two forms of CBZ-saccharin, the crystal packings display both homosynthon (double hydrogen bonds involving the carboxamide groups of CBZ) and heterosynthon (hydrogen bonds between the respective $\mathrm{N}-\mathrm{H}$ and $\mathrm{C}=\mathrm{O}$ moieties of $\mathrm{CBZ}$ and saccharine molecules) arrangements.

In the present work, we propose to go deeper into the understanding of the molecular interactions of CBZ beyond the crystal structure characterizations. For this purpose, we here describe the experimental and theoretical charge densities of CBZ molecule in the most stable form III (monoclinic, space group $\mathrm{P} 2_{1} / n$ ). Charge densities of CBZ were derived from accurate high resolution low temperature X-ray diffraction data and from first principal theoretical high 
level DFT calculations. Topological analysis of the electron density, atomic charges, electrostatic potential, and interaction energies of CBZ molecule are reported.

\section{EXPERIMENTAL AND METHODOLOGICAL SECTION}

Crystallization. Commercial carbamazepine was obtained from Enzo Life Sciences compagny and stored at $4^{\circ}$ C. Crystal samples of CBZ used in this study were obtained by slow evaporation of supersaturated solution $(99.3 \mathrm{mg} / \mathrm{ml})$ of methanol. To ensure complete dissolution, the tubes containing the solutions were placed for $5 \mathrm{~h}$ in an ultrasonic bath and heated to a temperature of $50^{\circ} \mathrm{C}$. The first crystals (prismatic colorless samples) appear after $4 \mathrm{~h}$ of evaporation at room temperature.

X-ray data Collection. The data of the CBZ were collected at 100.0(1) K on a Kappa CCD APEX II diffractometer using graphite monochromated MoK $\alpha$ X-radiation (wavelength $\lambda=0.71069 \AA$ ). The data spots were recorded as $\omega$-scans $\left(\Delta \omega=1.0^{\circ}\right)$ in order to reconstruct accurate three dimensional diffracted intensity peak profiles. The exposure times for the recorded frames vary from $10 \mathrm{~s}$ (low order data) to $30 \mathrm{~s}$ (high order data). 10913 unique reflections were collected up to a resolution of $\sin \theta_{\max } / \lambda=H / 2=1.05 \AA^{-1}$, where $H$ is the Bragg vector modulus. An empirical absorption correction was applied using SADABS ${ }^{22}$ computer program for the two data sets. SORTAV ${ }^{23}$ program was used for sorting and averaging data revealing the excellent quality of the measurements (internal $\mathrm{R}_{\text {int }}=$ 0.0163 with data redundancy between 13 and 15). Details of the X-ray diffraction experiment conditions and the crystallographic data for the CBZ compound are given in Table 1.

Spherical and Electron Density Refinements. The crystal structure of the CBZ compound was solved using SIR94 program ${ }^{24}$ and refined using SHELX97 ${ }^{25}$ implemented in WinGX ${ }^{26}$ package. For the electron density refinements, the Hansen-Coppens mode ${ }^{27}$ was used. The frozen core and normalized valence spherical densities are obtained from the Hartree-Fock wave functions of the free atoms or ions. ${ }^{28}$ The aspherical part of the pseudo-atom electron density is described by real normalized harmonics $y_{l m \pm}$ basis set $(l=0$ (monopole) to 4 (hexadecapole)) and modulated by a Slater-type radial function $R_{n l}(r)=N r^{n_{l}} \exp \left(-\xi_{l} r\right)$, where $N$ is a normalization factor. The exponents $^{29} \xi_{l}\left(\right.$ in bohr $\left.^{-1}\right)$ of the radial functions are chosen equal to 3.1, 4.5, 3.8 and $n_{l}=2,2,3$ up to octupoles $(l=$ 3) for $\mathrm{C}, \mathrm{O}$ and $\mathrm{N}$ atoms, respectively; $\xi_{l}=2.00 \mathrm{bohr}^{-1}$ and $n_{l}=1$ (dipole level, $l=1$ ) for the hydrogen atoms. 
MOPRO program ${ }^{30,31}$ was used for the electron density refinement against all the structure factors $F$ with no statistical standard deviations based cut-off $(I>0)$. Indeed, this program combines both conventional and conjugated gradient least-square procedures and requires all observed diffraction intensities. To obtain accurate atomic positions and atomic displacement parameters (ADP's) for non-H atoms, a high-order refinement was carried out using data with $\sin \theta_{\max } / \lambda>0.8 \AA^{-1}$; corresponding parameters for hydrogen atoms were refined against all data. In the first cycles of the refinements, chemical constraints on the multipole parameters were imposed for equivalent atoms of CBZ.

Deformation Electron Density Maps and Topological Analysis. The analysis of the topological features of the electron density was done following the AIM (Atoms in Molecules) theory. ${ }^{32}$ This analysis allows a quantitative description of the bonds and the electronic structure of atoms in molecules. The gradient of the electron density $\underline{\nabla} \rho\left(\underline{r}_{\mathrm{CP}}\right)$ vanishes at the critical points $(\mathrm{CP})$ corresponding to the extrema and saddle points of $\rho(\underline{\mathrm{r}})$. Each $\mathrm{CP}$ is therefore characterized by two numbers: the number of the eigenvalues (for non-degenerating cases) and the signature of the eigenvalues triplet $\left(\lambda_{1}, \lambda_{2}, \lambda_{3}\right)$. The ellipticity defined by $\varepsilon=\left(\lambda_{1}-\lambda_{2}\right) / \lambda_{2}$ is an index of the type of the chemical bonds $(\sigma$ or $\pi)$.

Experimental Electrostatic Potential and Interaction Energies. The electrostatic potential is based on the Hansen-Coppens electron density model. ${ }^{27,30,31}$ The electrostatic potential exhibits the nucleophilic (negative potential) and electrophilic (positive potential) regions of the molecule and is a good indicator of the chemical reactivity. The estimate of the electrostatic part of the interaction energy between molecules in the crystal was performed using the refined multipole parameters of each atom. ${ }^{30,31}$ The electrostatic interaction energy $\mathrm{E}_{\text {elec }}$ between two charge distributions A (through its charge density $\rho_{A}$ ) and B (through its electrostatic potential $\Phi_{B}$ ) is estimated by the integral

$$
E_{\text {elec }}=\int \rho_{A}(\underline{r}) \Phi_{B}(\underline{r}) d \underline{r}
$$

A and B can be chosen as fragments or entire molecules.

Theoretical calculations. The computations were carried out on isolated molecules, dimers or other interacting molecules in order to obtain a theoretical approach to the electron density and the electrostatic properties. The calculations were based on the experimental nuclei positions and no geometry optimization was performed. In 
order to provide a coherent overview (molecular and solid state) of the theoretical aspects, the quantum method was chosen to be within the Density Functional Theory (DFT) framework. Owing to the rather small size of the system, the highly flexible triple zeta basis set $6-311+\mathrm{G}(2 \mathrm{df}, 2 \mathrm{p})$ basis set was employed. ${ }^{35}$ Atomic charges and related topological properties were computed from the integrations over the atomic basin volumes ${ }^{32}$ using the AIM package $^{36}$. Deformations density maps were generated as a difference between the total theoretical electron density for a system and that derived from the Clementi's promolecule (sum of isolated atomic electron density contributions) also chosen as a reference in the experimental maps. ${ }^{28}$ Given the importance of the non H diffuse bonds, the hybrid M062X $\mathrm{X}^{33}$ functional available in Gaussian09 software ${ }^{34}$ was chosen. This approach has been known for its good performance in recent benchmarks.

\section{RESULTS AND DISCUSSION}

Crystal Structure. The numbering schemes for CBZ molecule are given in Figure 1. Form III of CBZ crystallizes in $\mathrm{P} 2{ }_{1} / n$ space group. The two first structure determinations of this polymorph have been carried out by two groups in the 80 's at two X-ray wavelengths $\left(\mathrm{CuK}_{\alpha}\right.$ or $\left.\mathrm{MoK}_{\alpha}\right) .{ }^{4}, 5$ In the present study, the atomic positions and ADP's were first refined using SHELX97 program. ${ }^{25}$ The values of these parameters were then improved after the multipole refinements. ${ }^{27}$ Significant variations of the geometrical features can be noticed when they are compared to the early reported results (and the estimated standard deviations) at room temperature. ${ }^{4,5}$

In the crystal lattice of form III, CBZ molecules are arranged as dimers and aromatic stackings as shown in Figure 2. The intermolecular interactions are characterized by $\mathrm{N}-\mathrm{H} \cdots \mathrm{O}$ hydrogen bonded dimers of CBZ molecules (centro-symmetrically connected) leading to homosynthon in an anti-dimer conformation, $\pi-\pi$ interactions between the benzene rings in two different conformations and $\mathrm{C}-\mathrm{H} \cdots \mathrm{O}, \mathrm{C}-\mathrm{H}^{\cdots} \cdots \pi$ and $\mathrm{N}-\mathrm{H}^{\cdots} \cdots \pi$ non-covalent interactions (Figure 2 and 
Table 2). The centroid-centroid CT2...CT2 $\pi-\pi$ interaction is called a sandwich herringbone (SH) shape ${ }^{10}$ while the CT1 ..CT2 $\pi-\pi$ interaction has not been explicitly labeled in the literature (Figure 2). In the following text we will quote $\pi-\pi \mathrm{SH}$ and $\pi-\pi$ these two interactions. The closest benzene rings (centroid-centroid CT2-CT2 distance of $3.784 \AA$ ) are those on the side of the $\mathrm{NH}_{2}$ groups of the $\mathrm{CBZ}$ molecule. ${ }^{10}$ Each of these rings interacts with the other benzene (CT1 centroid in Figure 2) at a longer distance of $3.901 \AA$. These values are in good agreement with those reported for the two monoclinic forms (III and IV) of CBZ. ${ }^{8}$ This four benzene ring stacking terminates with $\mathrm{C}-\mathrm{H} . . . \pi$ contacts involving the $\mathrm{H} 11$ hydrogen atoms $(\mathrm{C} 11-\mathrm{H} 11 \ldots \mathrm{C} 4$ equal to $2.773(8) \AA$ and $\mathrm{C} 11-\mathrm{H} 11 \ldots \mathrm{C} 5$ equal to $2.807(8) \AA$ ). Table 2 gives the features of the hydrogen bonds and close contacts found in the crystal lattice of form III of CBZ. The strongest hydrogen bonds occur between the oxygen $\mathrm{O} 1$ and the hydrogen $\mathrm{H} 15$ of the $\mathrm{NH}_{2}$ group with a short distance $\mathrm{H} 15 \ldots \mathrm{O} 1$ equal to $1.905(9) \AA\left(2.11(2)^{4}\right.$ and $2.04(2)^{5} \AA$ have been previously reported) with a $\mathrm{N}-\mathrm{H} . . . \mathrm{O}$ angle of $176.3^{\circ}(8)\left(174^{\circ}\right.$ and $178^{\circ} \AA$ found in references 4 and 5, respectively). The $\mathrm{H} 14$ hydrogen atom of the $\mathrm{NH}_{2}$ group is involved in the $\mathrm{N}-\mathrm{H} \ldots \pi$ interactions with short contact distances with the benzene C3 and C4 carbon atoms (Table 2). Two other hydrogen bonds involving $\mathrm{O} 1$ with $\mathrm{H} 8$ and $\mathrm{H} 12$ are observed at higher distances of 2.409(8) and 2.560(9) Å, respectively (Table 2).

Electron Density Maps. The theoretical and experimental static electron deformation density are depicted in Figure 3. In the experimental maps (right column of Figure 3), the observed peak heights are: 0.45 (O lone pairs), $0.55(\mathrm{C}-\mathrm{H}, \mathrm{C} 15-\mathrm{N} 2, \mathrm{~N}-\mathrm{H}), 0.50$ (C15-N1), 0.65 (aromatic $\mathrm{C}-\mathrm{C}), 0.75(\mathrm{C}=\mathrm{O})$ and $0.80 \mathrm{e}^{-3}(\mathrm{C} 7=\mathrm{C} 8)$, respectively. The oxygen lone pairs do not display any preferential polarization towards the H15 involved in the strong hydrogen bond of the CBZ dimer. Comparatively, the electron density peak heights found in the theoretical maps 
(left column of Figure 3) are as follows: $\mathrm{C} 7=\mathrm{C} 8\left(0.65 \mathrm{e}^{-3}\right), \mathrm{N} 1-\mathrm{C} 15\left(0.45 \mathrm{e}^{-3}\right), \mathrm{N} 2-\mathrm{C} 15(0.50$ $\left.\mathrm{e} \AA^{-3}\right), \mathrm{C} 15-\mathrm{O} 1\left(0.65 \mathrm{e}^{-3}\right), \mathrm{N} 2-\mathrm{H} 15\left(0.75 \mathrm{e}^{-3}\right), \mathrm{C} 9-\mathrm{C} 10\left(0.6 \mathrm{e}^{-3}\right), \mathrm{C} 3-\mathrm{H} 3\left(0.80 \mathrm{e}^{-3}\right)$ and 1.25 $\mathrm{e} \AA^{-3}$ for the oxygen lone pairs.

In the $\mathrm{H} 8 \cdots \mathrm{O} 1 \cdots \mathrm{H} 12$ plane, shown in Figure 4, the $\mathrm{O} 1$ lone pair is directed along the bisecting line of the $\mathrm{HOH}$ angle which is a characteristic of a bifurcated hydrogen bond and the lone pair electron density is more extended in the experimental map in comparison to the theoretical one. The experimental electron density is in very good agreement with that generated from the theoretical calculations (left column of Figure 4). The same promolecule density reference (Clementi spherical density ${ }^{28}$ ) has been chosen to plot the theoretical electron deformation density maps displayed in Figure 3. When the DFT basis set was chosen to reconstruct the promolecule density and to generate the deformation density, no significant difference was observed for $\mathrm{C}, \mathrm{H}$ or $\mathrm{O}$; for nitrogen atoms, however, the negative octupolar lobes close to the N1 and N2 nuclei are more pronounced for the DFT basis set promolecule reference by approximately $0.15 \mathrm{e}^{-3}$. Such a discrepancy seems to be somewhat constant whatever the quantum model used (DFT, HF, CASSCF) with any basis set, double zeta or superior.

Topology of the Experimental Electron density. We have carried out the topology of the experimental electron density following the theory of Bader ${ }^{32}$ The topological characteristics of the electron density of carbamazepine molecule are reported in Table 3. For all bonds within a given molecule, the Laplacian of the electron density is negative emphasizing their shared-shell or covalent character with $(3,-1)$ bond critical points (CP's). ${ }^{32}$ The C-C bonds of the two CBZ benzene rings exhibit the same topological characteristics with Laplacian values $\left(\nabla^{2} \rho\left(\underline{r}_{c} \mathrm{P}\right)\right)$ in the range of -18.13 to $-20.35 \mathrm{e}^{-5}$, electron densities equal to $2.0 \mathrm{e}^{-3}$ at the CP's located 
approximately in the middle of the bonds and bond ellipticity $\varepsilon$ around 0.2 ; this holds true for the C1-C6 and C9-C14 common bonds with the azepine ring. This latter exhibit higher values for the short $\mathrm{C} 7=\mathrm{C} 8$ double bond having a Laplacian equal to $-22.7 \mathrm{e} \AA^{-5}$, an electron density of $2.35 \mathrm{e}^{-3}$ at the $\mathrm{CP}$ (Table 3 ) and a high value of $\varepsilon$ equal to 0.23 . Both the remaining $\mathrm{C} 6-\mathrm{C} 7$ and $\mathrm{C} 8-\mathrm{C} 9$ bonds of the azepine ring reveal similar trends (Laplacian of $-14.5 \mathrm{e}^{-5}$ and $\rho\left(\mathrm{r}_{\mathrm{CP}}\right)$ of $1.9 \mathrm{e}^{-3}$ in average). All aromatic $\mathrm{C}-\mathrm{H}$ bonds in $\mathrm{CBZ}$ exhibit equivalent topological characters with Laplacian, electron density at CP's and ellipticity values of $-18 \mathrm{e}^{-5}, 1.8 \mathrm{e} \AA^{-3}$ and 0.06 , respectively. The topological features of the carboxamide group can be classified in four groups: $\mathrm{N} 1-\mathrm{C} 1$ and N1-C14 $\left(\nabla^{2} \rho\left(\underline{r}_{\mathrm{CP}}\right)=-13.6 \mathrm{e} \AA^{-5}\right.$ and $\rho\left(\underline{r}_{\mathrm{CP}}\right)=1.9 \mathrm{e} \AA^{-3}$ in average $)$ N1-C15 and N2$\mathrm{C} 15\left(\nabla^{2} \rho\left(\underline{r}_{\mathrm{CP}}\right)=-21.5\right.$ to $-26.4 \mathrm{e} \AA^{-5}$ and $\rho\left(\underline{r}_{\mathrm{CP}}\right)=2.2 \mathrm{e} \AA^{-3}$ in average $), \mathrm{N} 2-\mathrm{H} 14$ and $\mathrm{N} 2-\mathrm{H} 15$ $\left(\nabla^{2} \rho\left(\underline{r}_{C P}\right)=-32\right.$ e $\AA^{-5}$ and $\rho\left(\underline{r}_{C P}\right)=2.1$ e $\AA^{-3}$ in average $)$ and finally $\mathrm{C} 15=\mathrm{O} 1\left(\nabla^{2} \rho\left(\underline{r}_{\mathrm{CP}}\right)=-38.6 \mathrm{e} \AA^{-5}\right.$ and $\left.\rho\left(\underline{r}_{\mathrm{CP}}\right)=2.9 \mathrm{e}^{-3}\right)$. Comparatively, these values are similar to those reported for urea molecule. ${ }^{37}$

The Laplacian is positive (closed-shell type) for the hydrogen bonds and intermolecular contacts given in Table $2 .{ }^{32}$ The values reported in Table 3 illustrate the topological features of these weak interactions. In this case, the ellipticity $\varepsilon$ which is an index of the $\pi$ character of the covalent bond is not given for the hydrogen contacts. Both Laplacian and $\rho\left(r_{\mathrm{cp}}\right)$ values change with respect to the strength of the bond. The strongest hydrogen bond O1...H15 is characterized by high values of both $\rho\left(\mathrm{r}_{\mathrm{cp}}\right)$ and $\nabla^{2} \rho\left(\underline{\mathrm{r}}_{\mathrm{CP}}\right)$ found equal to $0.16 \mathrm{e}^{-3}$ and $2.58 \mathrm{e} \AA^{-5}$; other intermolecular contacts exhibit $\rho\left(\mathrm{r}_{\mathrm{cp}}\right)$ and $\nabla^{2} \rho\left(\underline{r}_{\mathrm{c} P}\right)$ in the close range of 0.04 to $0.06 \mathrm{e}^{-3}$ and 0.6 to $0.8 \mathrm{e}^{-5}$, respectively. The last column in Table 3 gives the total hydrogen bond interaction energy $\left(\mathrm{E}_{\mathrm{HB}}\right)$ obtained from the potential energy density at the $\mathrm{CP}\left(\mathrm{E}_{\mathrm{HB}}=\mathrm{V}\left(\underline{\mathrm{r}}_{\mathrm{CP}}\right) / 2\right) .{ }^{38}$ The 
strongest $\mathrm{N} 2-\mathrm{H} 15 \ldots \mathrm{O} 1$ hydrogen bond is characterized by a high value of $\mathrm{E}_{\mathrm{HB}}=-25.6 \mathrm{~kJ} / \mathrm{mol}$. Comparatively, the other hydrogen bonds and contacts have smaller energy values ranging from $-4.0(\mathrm{~N} 2-\mathrm{H} 14 \ldots \mathrm{C} 4)$ to $-6.5 \mathrm{~kJ} / \mathrm{mol}(\mathrm{C} 8-\mathrm{H} 8 \ldots \mathrm{O} 1)$. All these values are consistent with those previously reported in literature. 39,40

Atomic Charges. Table 4 lists the experimental and theoretical charges obtained for the CBZ molecule using the integration of the electron density over the Bader's atomic basins. ${ }^{32}$ The two approaches lead to similar features. The charges of the carboxamide group of CBZ are compared to those experimentally found in urea $^{37}$ and piracetam ${ }^{41}$ compounds. The best agreement is found between the experimental values found for the CBZ carboxamide atoms and that of form III of piracetam except for the C15 carbon (1.60 e for CBZ and 1.14 e for form III of piracetam). In contrast, theoretical charges of the carboxamide fragment are close to those obtained for urea molecule with highly charged C15 carbon atom $(+1.67$ e for urea and +1.92 e for $\mathrm{CBZ}$ from theoretical calculations). In the azepine ring, the most positive atoms are $\mathrm{C} 1$ $(+0.27$ e for experiment and +0.35 e for theory) and $\mathrm{C} 14(+0.24$ e for experiment and +0.32 e for theory) connected to the N1 nitrogen atom (-0.94 e for experiment and -1.19 e for theory), whereas the other connecting carbon atoms C6 and C9 are almost neutral (Table 4) for both approaches. The $\mathrm{C} 7=\mathrm{C} 8$ short bond is characterized by experimental atomic charges of $-0.17 \mathrm{e}$ (C7) and -0.14 e (C8) which are neutralized by the high positive charges of $\mathrm{H} 7$ and $\mathrm{H} 8(+0.16 \mathrm{e})$ whereas from theory all these atoms carry zero charge. These high experimental charge values of the $\mathrm{H} 7-\mathrm{C} 7=\mathrm{C} 8-\mathrm{H} 8$ part of the azepine ring are, however, consistent with the dominant formation of the carbamazepine-10,11-epoxyde metabolite in the liver. ${ }^{42}$ The remaining benzene $\mathrm{C}$ and $\mathrm{H}$ atoms of the CBZ molecule do not display particular features of charge transfer for both experimental and theoretical approaches. 
Electrostatic Potential. Figure 5 depicts the features of the electrostatic potential (equation 2) obtained from the experimental and theoretical data. The chosen representation of the electrostatic potential is the isovalue surfaces giving the extension of this property at a particular cut-off (here \pm 0.04 e. $\AA^{-1}$ ). For molecular compounds, the most interesting part of the electrostatic potential is the negative region (nucleophilic) where interactions with positive cations or hydrogenated species can occur. At first glance, theory and experiment yield similar electrostatic potential for isolated CBZ, dimer and pairs of molecules (Figure 5). From both theory and experiment, the isolated molecule and the H-bonded dimer exhibit a negative electrostatic potential envelop surrounding the $\mathrm{O} 1$ atom(s) of the carboxamide group(s) which comes in contact to the positive surface generated by the $\mathrm{NH}_{2}$ groups. The positive potential of this group is more contracted for the theoretical electrostatic potential than for experimental one. This is consistent with the total charge of the $\mathrm{NH}_{2}$ group reported in Table $4(-0.21$ e from experiment and -0.36 e from theory). Conversely, the negative region found in the vicinity of the azepine ring in experimental figures is more expanded. For the theoretical electrostatic potential, the negative region in the vicinity of the azepine ring is only observed on the side of the $\mathrm{C}=\mathrm{O}$ group(s). The right columns of Figure 5 illustrate the sandwich herringbone $\pi-\pi(\mathrm{SH})$ interaction between two neighboring CBZ molecules involving the (C9 to $\mathrm{C} 14$ ) benzene rings (see Figures 1 and 2). From experiment, the two positive regions of the interacting benzene rings are separated by an internal negative pocket which is more confined in the theoretical electrostatic potential shown in Figure 5. We also have carried out calculations of the electrostatic potential for a cluster of the four molecules interacting via aromatic-aromatic interactions as displayed in Figure 2. Figure 6 depicts the experimental and theoretical electrostatic potential generated by the cluster. The outer negative lobes from both theory and experiment are due to the $\mathrm{C}=\mathrm{O}$ groups of 
the CBZ molecules. However, the negative regions in the vicinity of the azepine rings shown in the experimental electrostatic potential figure are absent at the -0.04 e. $\AA^{-1}$ cut-off in the theoretical one, especially for the external CBZ molecules. However it is worthy to note that the addition of the two outer CBZ molecules and their benzene contributions increase the extension of the negative electrostatic potential pocket characterizing the $\pi-\pi \mathrm{SH}$ interaction in the theoretical figure.

Interaction and Binding Energies. The experimental estimate of the electrostatic interaction energies for $\mathrm{CBZ}$ molecules in the crystal environment is given in Table 5. The calculations were performed on pairs of CBZ interacting molecules (dimer, $\pi-\pi(\mathrm{SH})$ and the other $\pi-\pi$ stacking). The energies were also estimated for the hydrogen bonds and short contacts by only taking molecular fragments (only atoms involved in the interactions) as indicated in Table 5. The experimental value obtained for one hydrogen bond of the CBZ dimer in the present study $(-32.2 \mathrm{~kJ} / \mathrm{mol})$ is in excellent agreement with the previously reported coulombic energy $\left(\mathrm{E}_{\mathrm{coul}}=-32.7 \mathrm{~kJ} / \mathrm{mol}\right) .{ }^{10}$ For the pair of molecules involved in the $\pi-\pi \mathrm{SH}$ (sandwich herringbone) interaction a comparative value of $-32.37 \mathrm{~kJ} / \mathrm{mol}$ was found; the other $\pi-\pi$ interaction is characterized by a smaller value $(-23.10 \mathrm{~kJ} / \mathrm{mol})$. For comparison, the aromaticaromatic energy interaction has been extensively investigated from theoretical approaches and the energy components (electrostatic, dispersive, inductive, exchange repulsion) have been estimated..$^{43}$ In this last study, ${ }^{43}$ the researchers have shown that the dominant energy component in $\pi-\pi$ interaction is the dispersive energy whereas hydrogen bonds have an electrostatic character. For nearly parallel rings, the typical binding energies were found in the range of -10.9 $\left(\mathrm{C}_{6} \mathrm{H}_{6}\right)$ to $-18.2 \mathrm{~kJ} / \mathrm{mol}\left(\mathrm{C}_{6} \mathrm{H}_{5} \mathrm{CN}\right)$ with electrostatic contributions in the interval of -10.8 to -21 $\mathrm{kJ} / \mathrm{mol}$, respectively. ${ }^{43}$ These values are smaller than those reported in the present study from the 
crystal based experimental approach for the molecular pairs. When only benzene fragments are used in the calculations, the electrostatic interaction energies were found equal to $-8 \mathrm{~kJ} / \mathrm{mol}$ for both $\pi-\pi$ SH and the other $\pi-\pi$ contacts (Table 5) which are close to the reported values. ${ }^{43}$ On the other hand, for the hydrogen bonds with the $\mathrm{O} 1$ oxygen atom, the calculations only involving the $\mathrm{N}-\mathrm{H}$ and $\mathrm{C}=\mathrm{O}$ groups reproduce well the electrostatic interaction energy for the entire dimer $(-31.96 \mathrm{~kJ} / \mathrm{mol}$ for $\mathrm{O} 1 \cdots \mathrm{H} 15$ bond, Table 5). $\mathrm{O} 1 \cdots \mathrm{H} 8$ and $\mathrm{O} 1 \cdots \mathrm{H} 12$ exhibit the same interaction energy around $-11 \mathrm{~kJ} / \mathrm{mol}$ for the bifurcated hydrogen bond (Figure 5). These last values are qualitatively consistent with the hydrogen bond energy $\mathrm{E}_{\mathrm{HB}}$ given in Table 3 and discussed in the previous paragraph. For the $\mathrm{N}-\mathrm{H} \cdots \pi$ and $\mathrm{C}-\mathrm{H} \cdots \pi$ interactions, the electrostatic energy values found for the interacting fragments are much smaller (from -1.34 to $-2.41 \mathrm{~kJ} / \mathrm{mol}$ ).

In Table 5 are also given the binding energies (difference between the total energy of the pairs of molecules and the energies of each molecule) obtained from the present theoretical calculations. An excellent agreement between experiment and theory is found for the hydrogen bonded dimer and the $\pi-\pi$ stacking of CBZ molecules emphasizing the electrostatic character of these interactions. However, the theoretical binding energy found for the $\pi-\pi(\mathrm{SH})$ interaction is higher than the experimental electrostatic energy (-42.75 versus $-32.37 \mathrm{~kJ} / \mathrm{mol})$. This probably reflects the high contribution of the dispersive energy as reported elsewhere. ${ }^{43}$

\section{CONCLUSIONS}

Crystal structures of $\mathrm{CBZ}$ have been extensively investigated to reveal the interaction properties of this molecule and the comparison to similar molecules was made through the 
Cambridge Structural Database (CSD). ${ }^{44}$ Theoretical and experimental electron densities described here are in good agreement and yield qualitative and quantitative description of the CBZ electrostatic properties. The topological analysis of the electron density permits to characterize the covalent and hydrogen bonds in the CBZ crystal lattice. This analysis also permits to quantify the atomic charges which are higher in the carboxamide group than in the aromatic part of the CBZ molecule. The electrostatic potentials obtained from experiment and theory are in good agreement with an exception for the aromatic delocalized electron contribution which is more enhanced in experimental figures. The electrostatic potential illustrates how the CBZ molecules interact via hydrogen bonds and aromatic-aromatic stacking. This study is a part of an ANR NPLIN-4-drug project (Non Photochemical Light Induced Nucleation for drug). ${ }^{45}$ One of the hypothesis of the nucleation mechanism is based on the preexistence of molecular clusters in the supersaturated solution. For these molecular clusters, the polarisability tensor symmetry would play a crucial role in agreement with a optical Kerr effect. 46 A target molecule actually studied in our group is the CBZ molecule. In that context, an estimate of the binding energies has been carried out in this study. The results show clearly that the first stable dimer formed is that displaying the strongest $\mathrm{NH} \cdots \mathrm{O}$ hydrogen bond $(-64.42$ $\left.\mathrm{kJ} . \mathrm{mol}^{-1}\right)$. The second strongest cluster $\left(-32.37 \mathrm{~kJ} . \mathrm{mol}^{-1}\right)$ binds through the $\pi-\pi(\mathrm{SH})$ interaction. Considering these first two interactions, the crystal packing could be described as a $1 \mathrm{D}$ chain of homosynthons connecting each other through the $\pi-\pi(\mathrm{SH})$ interaction. When taking into account the third interaction $\left(-23.10 \mathrm{~kJ} \cdot \mathrm{mol}^{-1}\right)$ a $3 \mathrm{D}$ crystal packing is formed. 


\section{ASSOCIATED CONTENT}

Supporting Information. Crystallographic information file (CIF) is available free of charge via the internet at http://pubs.acs.org

\section{ACKNOWLEDGMENT}

This work was funded by ANR (Agence Nationale de la Recherche) NPLIN4drug grant. ${ }^{45}$ The CNRS, Université Paris Sud and Ecole Centrale Paris are acknowledged. 


\section{REFERENCES}

(1) Ortells, M. O.; Barrantes, G. E. British Journal of Pharmacology 2002, 136, 883-895.

(2) Hata, M.; Tanak, Y.; Kyoda, N.; Osakabe, T.; Yuki, H.; Ishii, I.; Kitada, M.; Neyaa, S.; Hoshino, T. Bioorganic \& Medicinal Chemistry, 2008, 16, 5134-5148.

(3) Yuki, H.; Honma, T.; Hata, M.; Hoshino T. Bioorganic \& Medicinal Chemistry, 2012, $20775-783$.

(4) Reboul, J. P.; Cristau, B.; Soyfer, J. C.; Astier, J. P. Acta Crystallogr. 1981, B37, 1844-1848.

(5) Himes, V. L.; Mighell, A. D.; De Camp, W. H. Acta Crystallogr. 1981, B37, 22422245.

(6) Lisgarten, J. N.; Palmer, R. A.; Saldanha, J. W. J. Crystallogr Spectrosc. Res. 1989, 19, 641-649.

(7) Lowes, M. M. J.; Caira, M. R.; Lötter, A. P.; van der Watt, J. G. J. Pharm. Sci. 1987, $76,744-752$.

(8) Lang, M.; Kampf, J. W.; Matzger, A. J. J. Pharm. Sci. 2002, 91, 1186-1190.

(9) Grzesiak, A. L.; Lang, M.; Kim, K.; Matzger, A. J. J. Pharm. Sci. 2003, 92, 22602271.

(10) Cruz Cabeza, A. J.; Day, G. M.; Samuel Motherwell, W. D.; Jones, W. Cryst. Growth Des. 2012, 6(8), 1858-1866. 
(11) Price, S. L. Acc. Chem. Res., 2009, 42 (1), 117-126

(12) Upadhyay, P.; Dantuluri, A. K.; Kumar, L.; Bansal A. K. J. Pharm. Sci. 2012 101(5), 1843-1851

(13) Sypek, K.; Burns, I. S.; Florence, A. J.; Sefcik, J. Cryst. Growth Des. 2012, 12(10), 4821-4828.

(14) Cruz Cabeza, A. J.; Day, G. M.; Samuel Motherwell, W. D.; Jones, W. ChemComm 2007, 1600-1602.

(15) Fabbiani, F. P. A.; Byrne, L. T.; McKinnon, J. J.; Spackman, M. A. CrystEngComm 2007, 9, 728-731.

(16) Kogan, A.; Popov, I.; Uvarov, V.; Cohen, S.; Aserin, A.; Garti, N. Langmuir 2008, 24, 722-733.

(17) Florence, A. J.; Johnston, A.; Price, S. L.; Nowell, H.; Kennedy, A. R.; Shankland N. J. Pharm. Sci., 2006, 95(9), 1918-1930.

(18) Johnston, A.; Johnston, B. F.; Kennedy, A. R.; Florence, A. J. CrystEngComm, 2008, 10, 23-25.

(19) Harris, R. K.; Ghi, P. Y.; Puschmann, H.; Apperley, D. C.; Griesser, U. J.; Hammond, R. B.; Ma, C.; Roberts, K. J.; Pearce, G. J.; Yates, J. R. ; Pickard, C. J. Organic Process Research \& Development 2005, 9, 902-910.

(20) Porter III, W. W.; Elie, S. C.; Matzger, A. J. Cryst. Growth Des. 2008, 8:1, 14-16. 
(21) Jayasankar, A.; Somwangthanaroj, A.; Shao, Z. J.; Rodriguez-Hornedo N. Pharmaceut Res, 2006, 23(10), 2381-2392.

(22) SADABS (Version 2.10). George Sheldrick, University of Göttingen, 2003.

(23) Blessing, R. H. J. Appl. Crystallogr. 1997, 30, 421-426.

(24) Altomare, A.; Cascarano, G.; Giacovazzo, C.; Guagliardi, A. J. Appl. Crystallogr. 1993, 26, 343-350.

(25) Sheldrick, G. M. Acta Crystallogr. 2008, A64, 112-122.

(26) Farrugia, L. J. WinGX (Version 1.80.03). J. Appl. Crystallogr. 1999, 32, 837-838.

(27) Hansen, N. K.; Coppens, P. Acta Crystallogr. 1978, A34, 909-921.

(28) Clementi, E.; Roetti, C. Atomic data and Nuclear data tables. Academic press, New York, USA, 1974, 14, 177.

(29) Clementi, E.; Raimondi, D.L. J. Chem. Phys. 1963, 41, 2686.

(30) Guillot, B.; Viry, L.; Guillot, R.; Lecomte, C.; Jelsch, C. J. Appl. Crystallogr. 2000, 34, 214-223.

(31) Jelsch, C.; Guillot, B.; Lagoutte, A.; Lecomte, C. J. Appl. Crystallogr. 2005, 38, $38-54$.

(32) Bader, R. F. W. Atoms in Molecules - A Quantum Theory; Clarendon Press: Oxford, 1990.

(33) Chai, J.-D.; Head-Gordon, M. Phys. Chem. Chem. Phys. 2008, 10, 6615-6620.

(34) Gaussian 09, Revision A.1, M. J. Frisch, G. W. Trucks, H. B. Schlegel, G. E. Scuseria, M. A. Robb, J. R. Cheeseman, G. Scalmani, V. Barone, B. Mennucci, G. A. Petersson, H. Nakatsuji, M. Caricato, X. Li, H. P. Hratchian, A. F. Izmaylov, J. Bloino, G. Zheng, J. L. Sonnenberg, M. Hada, M. Ehara, K. Toyota, R. Fukuda, J. 
Hasegawa, M. Ishida, T. Nakajima, Y. Honda, O. Kitao, H. Nakai, T. Vreven, J. A. Montgomery, Jr., J. E. Peralta, F. Ogliaro, M. Bearpark, J. J. Heyd, E. Brothers, K. N. Kudin, V. N. Staroverov, R. Kobayashi, J. Normand, K. Raghavachari, A. Rendell, J. C. Burant, S. S. Iyengar, J. Tomasi, M. Cossi, N. Rega, J. M. Millam, M. Klene, J. E. Knox, J. B. Cross, V. Bakken, C. Adamo, J. Jaramillo, R. Gomperts, R. E. Stratmann, O. Yazyev, A. J. Austin, R. Cammi, C. Pomelli, J. W. Ochterski, R. L. Martin, K. Morokuma, V. G. Zakrzewski, G. A. Voth, P. Salvador, J. J. Dannenberg, S. Dapprich, A. D. Daniels, Ö. Farkas, J. B. Foresman, J. V. Ortiz, J. Cioslowski, and D. J. Fox, Gaussian, Inc., Wallingford CT, 2009.

(35) Dunning Jr, T. H. J. Chem. Phys.1989, 90, 1007-1023.

(36) AIMAll (Version 10.12.16), Todd A. Keith, 2010 (aim.tkgristmill.com).

(37) Birkedal, H.; Madsen, D.; Mathiesen, R. H.; Knudsen, K.; Weber, H.-P.; Pattison, P.; Schwarzenbach, D. Acta Crystallogr. 2004, A60, 371-381.

(38) Espinosa, E.; Molins, E.; Lecomte C. Chem. Phys. Lett. 1998, 285, 170-173.

(39) Malecka, M.; Checinska, L.; Rybarczyk-Pirek, A.; Morgenroth, W.; Paulmann, C. Acta Crystallogr. 2010, B66, 687-695.

(40) Liebschner, D.; Jelsch, C.; Espinosa, E.; Lecomte, C.; Chabrière, E.; Guillot, B. J. Phys. Chem. A. 2011, 115(45),12895-12904.

(41) Chambrier, M.H.; Bouhmaida, N.; Bonhomme, F.; Lebègue, S.; Gillet, J.M.; Jelsch, C.; Ghermani, N.E. Cryst. Growth Des. 2011, 11, 2528-2539.

(42) Breton, H.; Cociglio, M.; Bressolle, F.; Peyriere, H.; Blayac, J. P.; HillaireBuys, D. Journal of Chromatography B 2005, 828, 80-90.

(43) Singh, N. J.; Min, S. K.; Kim, D. Y.; Kim, K. S. J. Chem. Theory Comp. 2009, 5, 515-529. 
(44) Childs, S. L.; Wood, P. A.; Rodriguez-Hornedo, N.; Reddy, L. S.; Hardcastle, K. I. Cryst. Growth Des. 2009, 9, 1869-1888.

(45) http://www.agence-nationale-recherche.fr/en/anr-funded-project/tx_lwmsuivibilan _ pi2[CODE] $=$ ANR-10-NANO-0017

(46) Garetz, B. A.; Matic, J.; Myerson, A. S. Phys. Rev. Lett. 2002, 89(17) 175501. 
Table 1. Data Collection and Refinement Details.

\begin{tabular}{|c|c|}
\hline Empirical formula & $\mathrm{C}_{15} \mathrm{H}_{12} \mathrm{~N}_{2} \mathrm{O}$ \\
\hline Formula weight & 236.257 \\
\hline Temperature (K) & $100.0(1)$ \\
\hline Crystal size $\left(\mathrm{mm}^{3}\right)$ & $0.25 \times 0.23 \times 0.15$ \\
\hline Crystal system & Monoclinic \\
\hline Space group & $\mathrm{P} 2{ }_{1} / \mathrm{n}$ \\
\hline \multirow[t]{6}{*}{ Unit cell dimensions } & $a=7.4874(2) \AA$ \\
\hline & $b=11.0406(3) \AA$ \\
\hline & $c=13.7754(4) \AA$ \\
\hline & $\alpha=90.00^{\circ}$ \\
\hline & $\beta=92.939(1)^{\circ}$ \\
\hline & $\gamma=90.00^{\circ}$ \\
\hline Volume & $1137.25(1) \AA^{3}$ \\
\hline Z & 4 \\
\hline Density (calculated) $\left(\mathrm{Mg} / \mathrm{m}^{3}\right)$ & 1.380 \\
\hline Absorption coefficient $\left(\mathrm{mm}^{-1}\right)$ & 0.089 \\
\hline$\theta$ range for data collection $\left(^{\circ}\right)$ & 0 to 48.3 \\
\hline$[(\sin \theta) / \lambda]_{\max }\left(\AA^{-1}\right)$ & 1.05 \\
\hline \# Collected reflections & 144720 \\
\hline \# Independent reflections & $10913\left[R_{\text {int }}=0.0163\right]$ \\
\hline \multicolumn{2}{|l|}{ Spherical Refinement } \\
\hline$R_{1}, w R_{2}$, gof $[I>2 \operatorname{sigma}(I)]$ & $0.0306,0.0975,0.963$ \\
\hline \multicolumn{2}{|l|}{ Multipole Refinement } \\
\hline$R_{1}(\mathrm{~F}), \quad w R_{2}(\mathrm{~F}), \quad$ gof $\quad[I>0]$ & $0.0114,0.0108,0.589$ \\
\hline
\end{tabular}


Table 2. Selected bond lengths $(\AA)$ and angles $\left({ }^{\circ}\right)$. Standard deviations are given in parentheses.

\begin{tabular}{|c|c|c|c|c|c|c|c|}
\hline N1 & $\mathrm{C} 15$ & $1.3815(5)$ & $\mathrm{C} 1$ & N1 & $\mathrm{C} 14$ & $117.13(3)$ & \\
\hline N2 & $\mathrm{C} 15$ & $1.3566(4)$ & $\mathrm{O} 1$ & $\mathrm{C} 15$ & $\mathrm{~N} 2$ & $122.26(3)$ & \\
\hline \multirow[t]{2}{*}{$\mathrm{C} 15$} & $\mathrm{O} 1$ & $1.2384(4)$ & & & & & \\
\hline & & & $\mathrm{C} 7$ & $\mathrm{C} 8$ & C9 & $126.25(3)$ & \\
\hline N1 & $\mathrm{C} 1$ & $1.4302(4)$ & C6 & $\mathrm{C} 7$ & C8 & $127.75(3)$ & \\
\hline \multirow[t]{2}{*}{ N1 } & $\mathrm{C} 14$ & $1.4316(4)$ & & & & & \\
\hline & & & $\mathrm{C} 8$ & C9 & $\mathrm{C} 14$ & $123.04(3)$ & \\
\hline C9 & $\mathrm{C} 14$ & $1.4041(4)$ & $\mathrm{C} 1$ & C6 & $\mathrm{C} 7$ & $123.44(3)$ & \\
\hline $\mathrm{C} 1$ & C6 & $1.4054(4)$ & & & & & \\
\hline $\mathrm{C} 8$ & C9 & $1.4624(5)$ & N1 & $\mathrm{C} 14$ & C9 & $\mathrm{C} 8$ & $-7.02(5)$ \\
\hline \multirow[t]{2}{*}{ C6 } & $\mathrm{C} 7$ & $1.4619(5)$ & $\mathrm{C} 7$ & $\mathrm{C} 8$ & C9 & $\mathrm{C} 14$ & $-31.12(6)$ \\
\hline & & & $\mathrm{C} 6$ & $\mathrm{C} 7$ & $\mathrm{C} 8$ & $\mathrm{C} 9$ & $1.92(6)$ \\
\hline \multirow[t]{2}{*}{$\mathrm{C} 7$} & $\mathrm{C} 8$ & $1.3520(6)$ & $\mathrm{C} 1$ & C6 & $\mathrm{C} 7$ & $\mathrm{C} 8$ & $32.01(6)$ \\
\hline & & & N1 & $\mathrm{C} 1$ & C6 & $\mathrm{C} 7$ & $0.82(5)$ \\
\hline $\mathrm{C} 5$ & C6 & $1.4080(4)$ & C6 & $\mathrm{C} 1$ & N1 & C14 & $-63.80(4)$ \\
\hline $\mathrm{C} 4$ & C5 & $1.3883(5)$ & $\mathrm{C} 1$ & N1 & C14 & C9 & $68.50(4)$ \\
\hline $\mathrm{C} 3$ & $\mathrm{C} 4$ & $1.3966(6)$ & & & & & \\
\hline $\mathrm{C} 2$ & C3 & $1.3930(6)$ & & & & & \\
\hline $\mathrm{C} 1$ & $\mathrm{C} 2$ & $1.3959(5)$ & & & & & \\
\hline C9 & $\mathrm{C} 10$ & $1.4063(5)$ & & & & & \\
\hline $\mathrm{C} 10$ & $\mathrm{C} 11$ & $1.3882(6)$ & $\mathrm{O} 1$ & $\mathrm{C} 15$ & N1 & $\mathrm{C} 1$ & $9.36(5)$ \\
\hline C11 & $\mathrm{C} 12$ & $1.3959(6)$ & & & & & \\
\hline $\mathrm{C} 12$ & $\mathrm{C} 13$ & $1.3936(6)$ & & & & & \\
\hline $\mathrm{C} 13$ & C14 & $1.3988(5)$ & & & & & \\
\hline
\end{tabular}

Hydrogen bonds

$\begin{array}{llllll}\mathrm{N} 2-\mathrm{H} 15 \ldots \mathrm{O}^{1} & 1.905(9) & \mathrm{N} 2 & \mathrm{H} 15 & \mathrm{O}^{1} & 176.3(8) \\ \mathrm{C} 8-\mathrm{H} 8 \ldots 1^{2} & 2.409(8) & \mathrm{C} 8 & \mathrm{H} 8 & \mathrm{O}^{2} & 165.7(8) \\ \mathrm{C} 12-\mathrm{H} 12 \ldots{ }^{3} & 2.560(9) & \mathrm{C} 12 & \mathrm{H} 12 & \mathrm{O}^{3} & 138.8(7)\end{array}$

Intermolecular contacts

$\begin{array}{ll}\mathrm{N} 2-\mathrm{H} 14 \ldots \mathrm{C} 3^{3} & 2.737(8) \\ \mathrm{N} 2-\mathrm{H} 14 \ldots \mathrm{C} 4^{3} & 2.749(8) \\ \mathrm{C} 11-\mathrm{H} 11 \ldots \mathrm{C} 4^{4} & 2.773(8) \\ \mathrm{C} 11-\mathrm{H} 11 \ldots \mathrm{C} 5^{4} & 2.807(8)\end{array}$

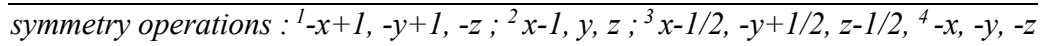


Table 3. Topological properties of the experimental electron density of carbamazepine. $\rho\left(\underline{r}_{C P}\right)$ and $\nabla^{2} \rho(\underline{\mathbf{r}} \mathrm{CP})$ are the electron density and the Laplacian values at the critical points (CP); $\varepsilon$ is the ellipticity of the bond. $E_{H B}$ (in $\mathrm{kJ} / \mathrm{mol}$ ) indicates the hydrogen bond energy.

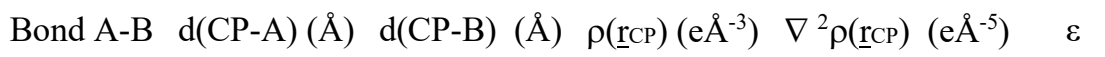

$\begin{array}{llllll}\text { N1-C1 } & 0.814 & 0.616 & 1.92 & -13.8 & 0.075 \\ \text { N1-C14 } & 0.814 & 0.618 & 1.92 & -13.6 & 0.068 \\ \text { N1-C15 } & 0.802 & 0.580 & 2.18 & -21.5 & 0.184\end{array}$

N2-C15 $\quad 0.808 \quad 0.549 \quad 2.29$

$\begin{array}{llll}\mathrm{N} 2-\mathrm{H} 14 & 0.758 & 0.250 & 2.14\end{array}$

$\begin{array}{llll}\mathrm{N} 2-\mathrm{H} 15 & 0.759 & 0.250 & 2.13\end{array}$

$\begin{array}{llll}\mathrm{O} 1-\mathrm{C} 15 & 0.777 & 0.462 & 2.89\end{array}$

$\begin{array}{llll}\mathrm{C} 1-\mathrm{C} 2 & 0.713 & 0.683 & 2.19\end{array}$

$\begin{array}{llll}\mathrm{C} 2-\mathrm{C} 3 & 0.695 & 0.698 & 2.17\end{array}$

$\begin{array}{llll}\mathrm{C} 3-\mathrm{C} 4 & 0.690 & 0.707 & 2.17\end{array}$

$\begin{array}{llll}\mathrm{C} 4-\mathrm{C} 5 & 0.702 & 0.686 & 2.19\end{array}$

$\begin{array}{llll}\mathrm{C} 5-\mathrm{C} 6 & 0.698 & 0.710 & 2.11\end{array}$

$\begin{array}{llll}\mathrm{C} 6-\mathrm{C} 1 & 0.695 & 0.710 & 2.15\end{array}$

$\begin{array}{llll}\mathrm{C} 2-\mathrm{H} 2 & 0.733 & 0.350 & 1.79\end{array}$

$\begin{array}{llll}\mathrm{C} 3-\mathrm{H} 3 & 0.733 & 0.350 & 1.77\end{array}$

$\begin{array}{llll}\mathrm{C} 4-\mathrm{H} 4 & 0.739 & 0.345 & 1.79\end{array}$

$\begin{array}{llll}\mathrm{C} 5-\mathrm{H} 5 & 0.732 & 0.350 & 1.77\end{array}$

$\begin{array}{llll}\mathrm{C} 6-\mathrm{C} 7 & 0.733 & 0.729 & 1.90\end{array}$

$\begin{array}{llll}\mathrm{C} 7-\mathrm{C} 8 & 0.676 & 0.676 & 2.35\end{array}$

$\begin{array}{llll}\mathrm{C} 8-\mathrm{C} 9 & 0.734 & 0.728 & 1.89\end{array}$

$\begin{array}{llll}\mathrm{C} 7-\mathrm{H} 7 & 0.734 & 0.351 & 1.76\end{array}$

\begin{tabular}{|c|c|c|c|c|c|c|c|}
\hline-13.8 & 0.075 & C8-H8 & 0.733 & 0.350 & 1.76 & -17.1 & 0.049 \\
\hline-13.6 & 0.068 & C9-C10 & 0.705 & 0.702 & 2.12 & -18.5 & 0.168 \\
\hline-21.5 & 0.184 & $\mathrm{C} 10-\mathrm{C} 11$ & 0.686 & 0.702 & 2.19 & -20.4 & 0.167 \\
\hline-26.4 & 0.160 & $\mathrm{C} 11-\mathrm{C} 12$ & 0.706 & 0.690 & 2.17 & -19.9 & 0.168 \\
\hline-32.1 & 0.060 & $\mathrm{C} 12-\mathrm{C} 13$ & 0.698 & 0.696 & 2.17 & -19.9 & 0.172 \\
\hline-31.8 & 0.061 & $\mathrm{C} 13-\mathrm{C} 14$ & 0.685 & 0.714 & 2.18 & -20.0 & 0.203 \\
\hline-38.6 & 0.097 & C14-C9 & 0.714 & 0.690 & 2.16 & -19.2 & 0.201 \\
\hline-20.2 & 0.204 & $\mathrm{C} 10-\mathrm{H} 10$ & 0.734 & 0.351 & 1.77 & -17.2 & 0.053 \\
\hline-20.0 & 0.172 & $\mathrm{C} 11-\mathrm{H} 11$ & 0.738 & 0.345 & 1.79 & -18.0 & 0.057 \\
\hline-19.8 & 0.168 & $\mathrm{C} 12-\mathrm{H} 12$ & 0.732 & 0.350 & 1.78 & -17.5 & 0.054 \\
\hline-20.4 & 0.167 & C13-H13 & 0.734 & 0.351 & 1.79 & -17.8 & 0.064 \\
\hline-18.1 & 0.170 & & & & & & \\
\hline-18.9 & 0.201 & \multicolumn{5}{|c|}{ Hydrogen bonds and intermolecular contacts } & $E_{H B}$ \\
\hline-18.0 & 0.063 & & & & & & \\
\hline-17.4 & 0.054 & $\mathrm{~N} 2-\mathrm{H} 15 \ldots \mathrm{O} 1^{1}$ & 0.641 & 1.263 & 0.16 & 2.6 & -25.6 \\
\hline-17.9 & 0.056 & $\mathrm{C} 8-\mathrm{H} 8 \ldots \mathrm{O}^{2}$ & 0.947 & 1.443 & 0.06 & 0.8 & -6.5 \\
\hline-17.3 & 0.050 & $\mathrm{C} 12-\mathrm{H} 12 \ldots \mathrm{O}^{3}$ & 0.897 & 1.486 & 0.05 & 0.7 & -5.0 \\
\hline-14.6 & 0.111 & $\mathrm{~N} 2-\mathrm{H} 14 \ldots \mathrm{C} 3^{3}$ & 1.665 & 0.856 & 0.04 & 0.5 & -4.1 \\
\hline-22.7 & 0.234 & $\mathrm{~N} 2-\mathrm{H} 14 \ldots \mathrm{C} 4^{3}$ & 1.696 & 0.914 & 0.04 & 0.5 & -4.0 \\
\hline-14.5 & 0.120 & $\mathrm{C} 11-\mathrm{H} 11 \ldots \mathrm{C} 4^{4}$ & 1.954 & 0.863 & 0.05 & 0.6 & -5.0 \\
\hline-16.92 & 0.048 & C11-H11...C5 & 1.763 & 0.794 & 0.05 & 0.6 & -5.0 \\
\hline
\end{tabular}

symmetry operations $:{ }^{1}-x+1,-y+1,-z ;{ }^{2} x-1, y, z ;{ }^{3} x-1 / 2,-y+1 / 2, z-1 / 2,{ }^{4}-x,-y,-z$ 
Table 4. Atomic charges (in e unit) of $\mathrm{CBZ}$ and comparison to the experimental charges found in piracetam ${ }^{34}$ and urea ${ }^{30}$.

\begin{tabular}{|c|c|c|c|c|c|c|}
\hline \multicolumn{3}{|c|}{ CBZ } & \multicolumn{3}{|c|}{ Piracetam } & \multirow[t]{2}{*}{ Urea } \\
\hline & Experiment & theory & form II & form III & monohydrate & \\
\hline N1 & -0.94 & -1.19 & -0.92 & -0.91 & -1.03 & \\
\hline N2 & -1.09 & -1.20 & -1.05 & -1.07 & -1.28 & -1.21 \\
\hline $\mathrm{O} 1$ & -0.86 & -1.23 & -1.02 & -0.99 & -1.03 & -1.18 \\
\hline $\mathrm{C} 15$ & 1.60 & 1.92 & 1.41 & 1.14 & 1.12 & 1.67 \\
\hline H14 & 0.43 & 0.41 & 0.38 & 0.42 & 0.54 & 0.49 \\
\hline H15 & 0.45 & 0.43 & 0.38 & 0.44 & 0.52 & 0.48 \\
\hline $\mathrm{C} 2$ & 0.04 & 0.02 & & & & \\
\hline $\mathrm{C} 3$ & 0.02 & -0.00 & & & & \\
\hline $\mathrm{C} 4$ & -0.21 & -0.01 & & & & \\
\hline $\mathrm{C} 5$ & 0.05 & -0.01 & & & & \\
\hline $\mathrm{H} 2$ & 0.05 & 0.04 & & & & \\
\hline $\mathrm{H} 3$ & 0.13 & 0.02 & & & & \\
\hline $\mathrm{H} 4$ & 0.15 & 0.02 & & & & \\
\hline H5 & 0.02 & 0.01 & & & & \\
\hline $\mathrm{C} 7$ & -0.17 & -0.00 & & & & \\
\hline $\mathrm{C} 8$ & -0.14 & -0.01 & & & & \\
\hline $\mathrm{H} 7$ & 0.16 & 0.02 & & & & \\
\hline $\mathrm{H} 8$ & 0.16 & 0.02 & & & & \\
\hline $\mathrm{C} 14$ & 0.24 & 0.32 & & & & \\
\hline $\mathrm{C} 1$ & 0.27 & 0.35 & & & & \\
\hline C9 & -0.02 & -0.00 & & & & \\
\hline C6 & 0.00 & -0.00 & & & & \\
\hline $\mathrm{C} 10$ & -0.16 & -0.01 & & & & \\
\hline $\mathrm{C} 11$ & -0.08 & -0.01 & & & & \\
\hline $\mathrm{C} 12$ & -0.11 & -0.01 & & & & \\
\hline $\mathrm{C} 13$ & -0.06 & -0.02 & & & & \\
\hline $\mathrm{H} 10$ & 0.15 & 0.02 & & & & \\
\hline H11 & 0.08 & 0.02 & & & & \\
\hline H12 & 0.15 & 0.02 & & & & \\
\hline H13 & 0.14 & 0.04 & & & & \\
\hline
\end{tabular}


Table 5. Experimental Electrostatic interaction Eelec(exp) and theoretical binding Ebind(theo) energies (in $\mathrm{kJ} / \mathrm{mol}$ ) of CBZ.

\begin{tabular}{|c|c|c|}
\hline Molecular interaction & $E_{\text {elec }}(\exp )$ & $E_{\text {bind }}($ theo $)$ \\
\hline $\operatorname{dimer}^{a}$ & -64.42 & -60.38 \\
\hline$\pi-\pi \mathrm{SH}^{b}$ & -32.37 & -42.75 \\
\hline$\pi-\pi^{c}$ & -23.10 & -24.76 \\
\hline \multicolumn{3}{|l|}{ Interacting fragments } \\
\hline$\pi-\pi \mathrm{SH}^{b}$ & -7.76 & \\
\hline$\pi-\pi^{c}$ & -8.15 & \\
\hline $\mathrm{N} 2-\mathrm{H} 15 \ldots \mathrm{O} 1-\mathrm{C} 15^{a}$ & -31.96 & \\
\hline $\mathrm{C} 8-\mathrm{H} 8 \ldots \mathrm{O} 1-\mathrm{C} 15^{d}$ & -11.81 & \\
\hline $\mathrm{C} 12-\mathrm{H} 12 \ldots \mathrm{O} 1-\mathrm{C} 15^{c}$ & -11.04 & \\
\hline $\mathrm{N} 2-\mathrm{H} 14 \ldots \mathrm{C} 3-\mathrm{H} 3^{c}$ & -2.41 & \\
\hline $\mathrm{N} 2-\mathrm{H} 14 \ldots \mathrm{C} 4-\mathrm{H} 4^{c}$ & -1.34 & \\
\hline $\mathrm{C} 11-\mathrm{H} 11 \ldots \mathrm{C} 4-\mathrm{H} 4^{b}$ & -2.13 & \\
\hline $\mathrm{C} 11-\mathrm{H} 11 \ldots \mathrm{C} 5-\mathrm{H}^{b}$ & -2.71 & \\
\hline
\end{tabular}




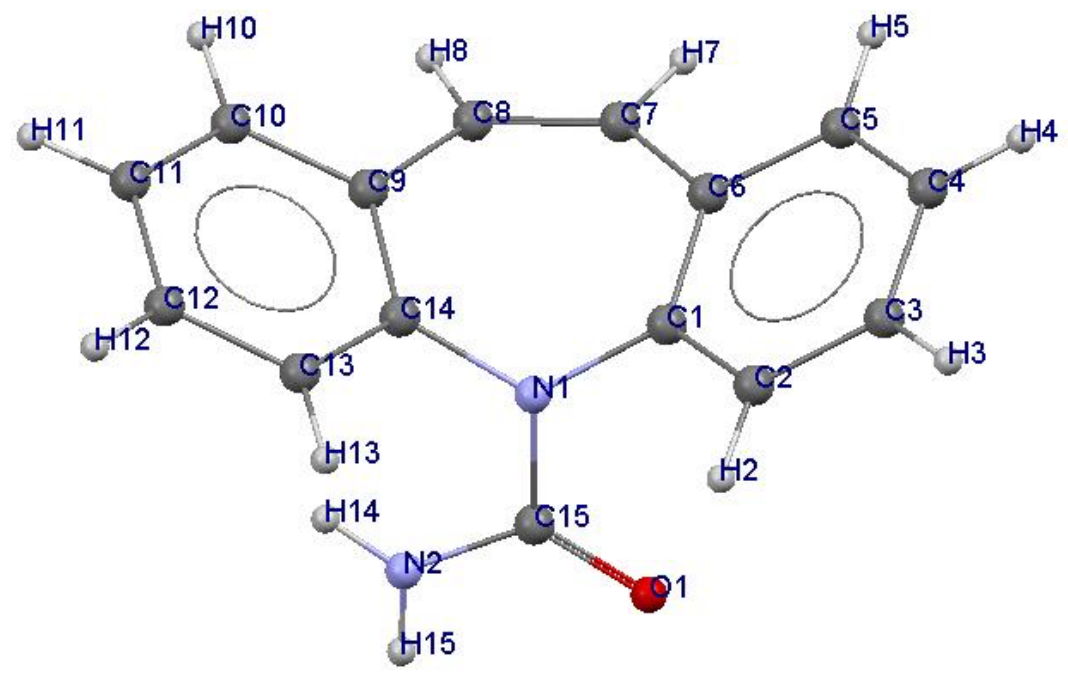

Figure 1. Molecular structure of CBZ with the numbering schemes of the atoms.

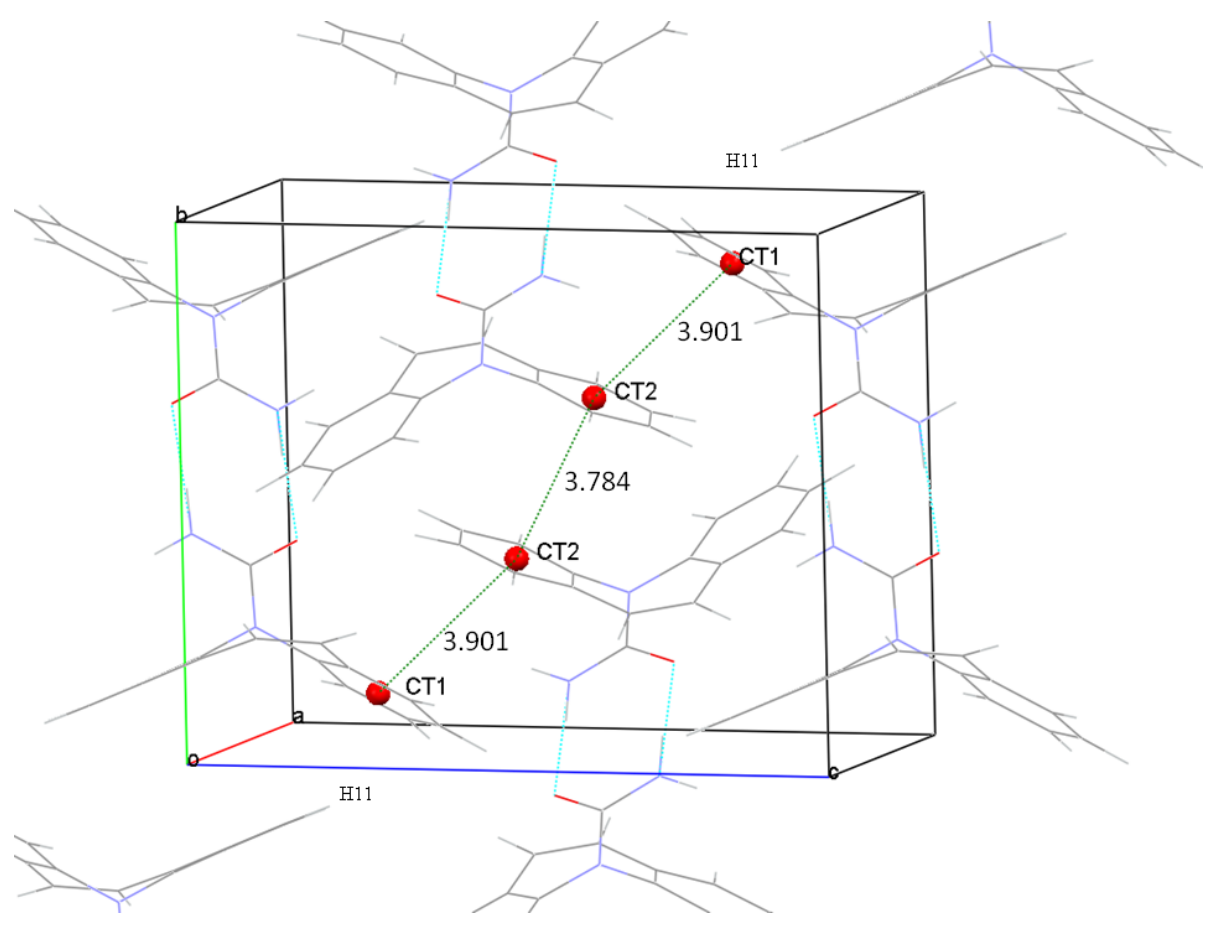

Figure 2. Molecular packing and hydrogen bonds in the crystal lattice of CBZ. Centroid-centroid distances between the benzene rings (differentiated by the labels CT1 and CT2) are indicated in $\AA$. H11 hydrogen atom involved in $\mathrm{CH} . . . \pi$ interaction is displayed. The centre of symmetry lies in the middle of the unit cell. 

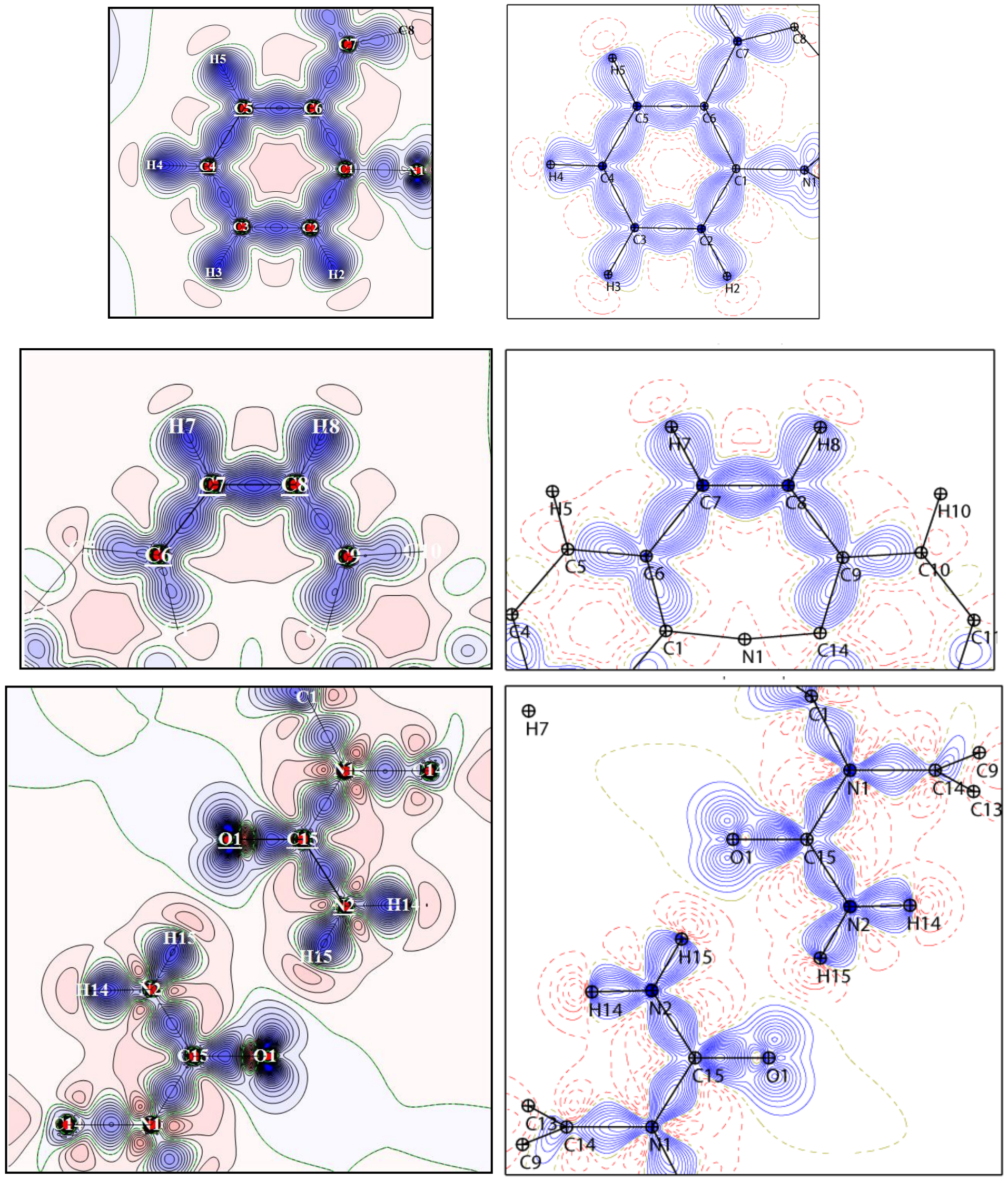

Figure 3. Theoretical (left column for isolated molecule and a dimer of molecules in the last row) and experimental static electron deformation density (right column) in chosen planes of CBZ molecule. Contours are $0.05 \mathrm{e}^{-3}$, negative contours are dashed. 

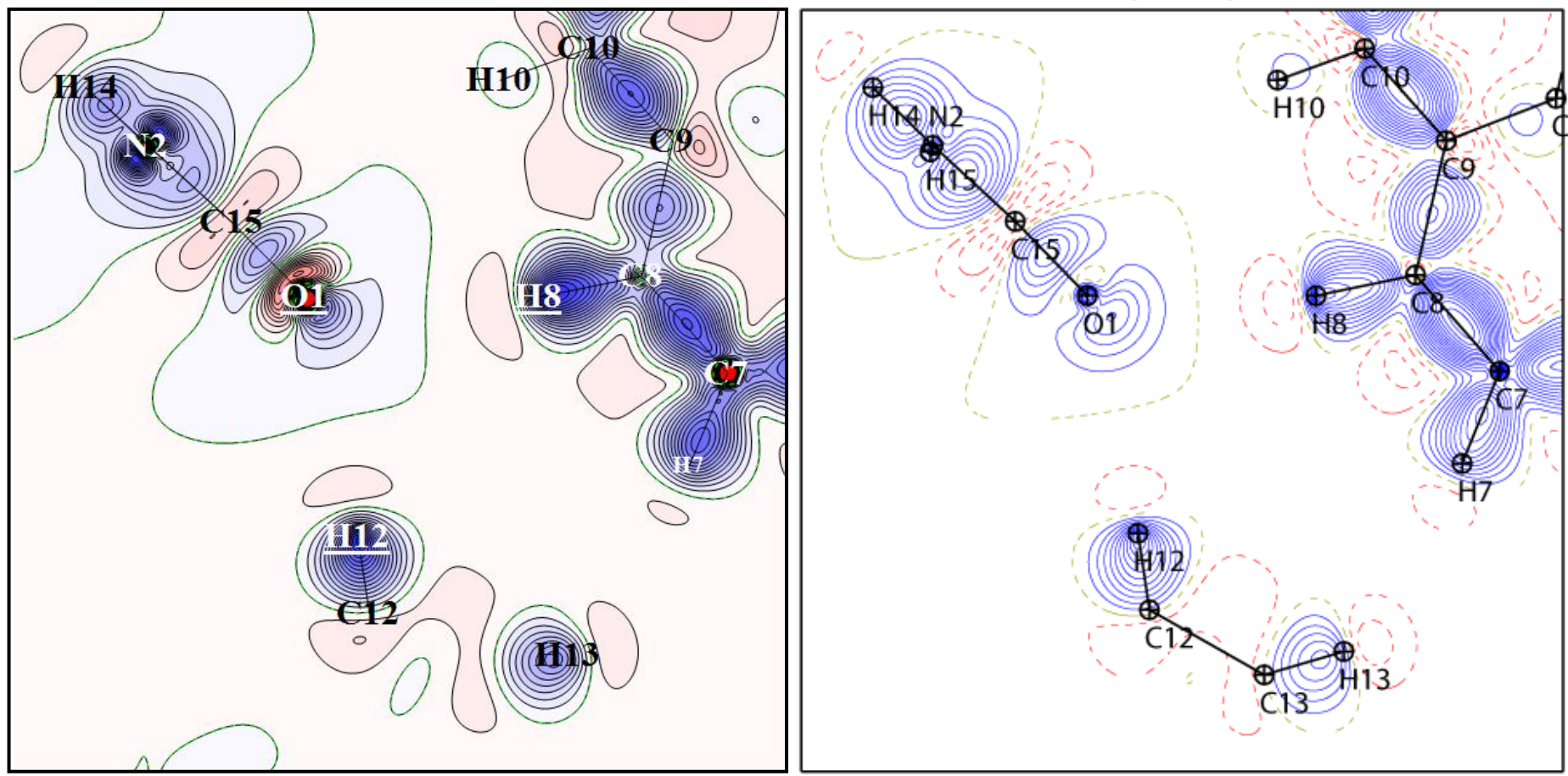

Figure 4. Theoretical (left) and experimental static electron deformation density (right) showing the C-H...O hydrogen bonds in CBZ form III crystal lattice. Contours are $0.05 \mathrm{e}^{-3}$, negative contours are dashed. 

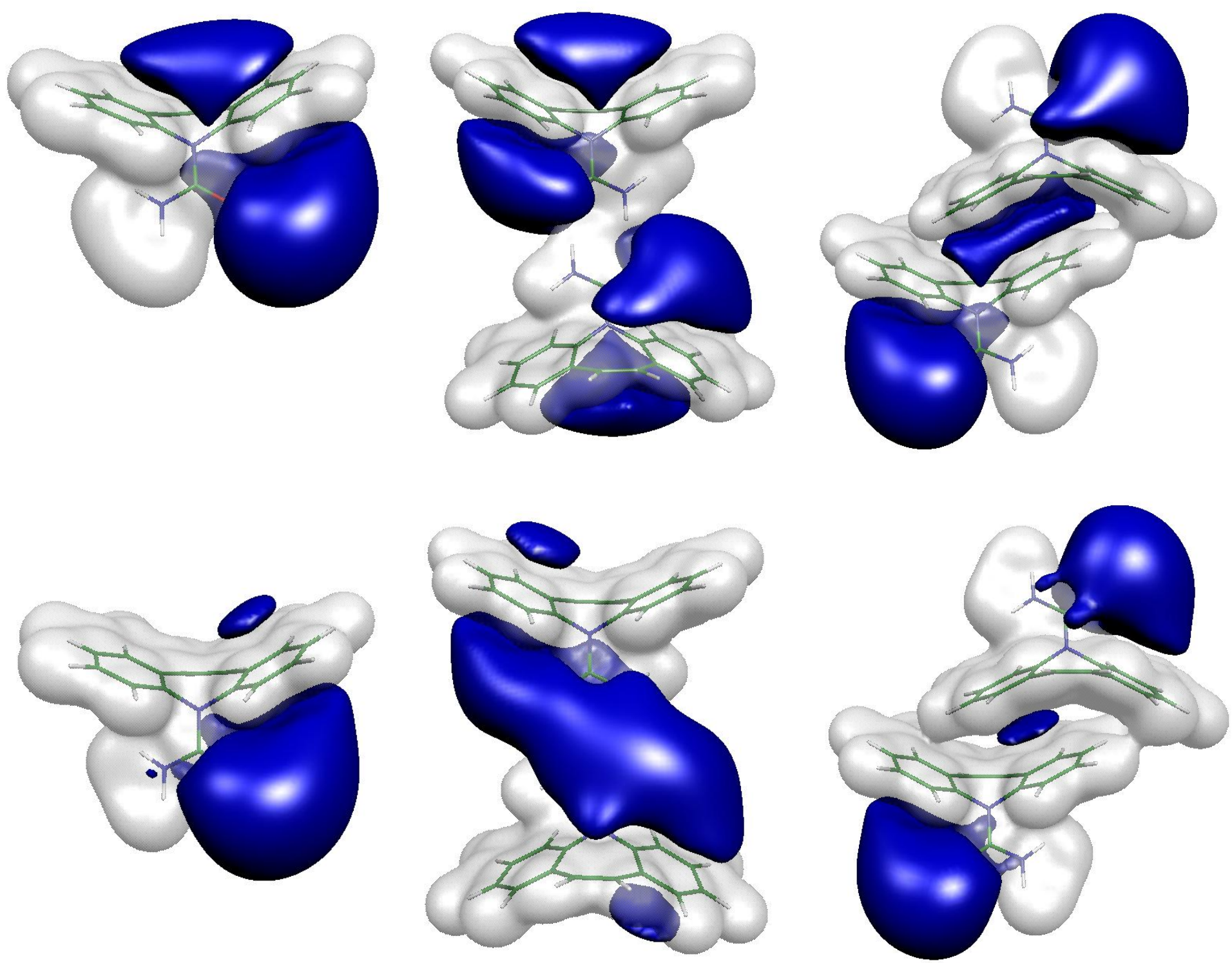

Figure 5. Experimental (first row) and theoretical (second row) electrostatic potential for an isolated molecule (left), the hydrogen bonded dimer (middle) and aromatic-aromatic interacting molecules of CBZ (sandwich herringbone). Isovalue surface cut-off is $\pm 0.04 \mathrm{e}^{-1}$, positive potential isosurface is in grey and the negative one is in blue. 

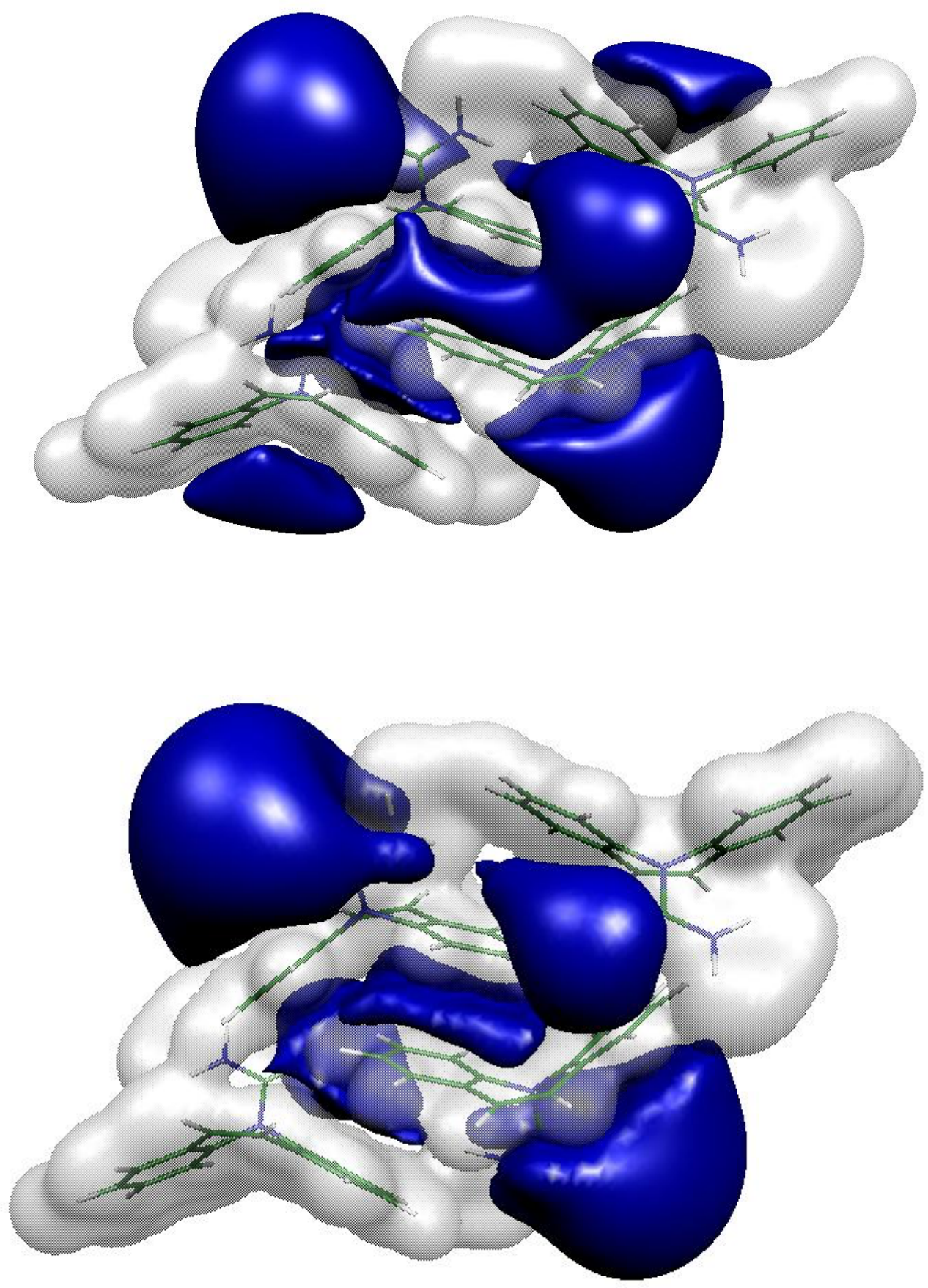

Figure 6. Experimental (first row) and theoretical (second row) electrostatic potential for a cluster of molecules (see Figure 2). Isovalue surface cut-off is $\pm 0.04 \mathrm{e}^{-1}$, positive potential isosurface is in grey and the negative one is in blue. 